\title{
Ecological characterisation of the Colombian entomopathogenic nematode Heterorhabditis sp. SL0708
}

\author{
Mejia-Torres, $M C .^{a *}$ and Sáenz, $A .^{b}$ \\ aLaboratorio de Control Biológico, Pontificia Universidad Javeriana - HPUJ, \\ Cra 7a No 43-82 Ed 54 (Jesús Emilio Ramírez)

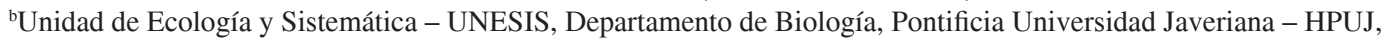 \\ Cra 7a No 43-82 Ed 54 (Jesús Emilio Ramirez), Of. 200 \\ *e-mail: mariacamila30@gmail.com
}

Received March 9, 2012 - Accepted May 18, 2012 - Distributed May 31, 2013

(With 5 figures)

\begin{abstract}
The entomopathogenic nematode Heterorhabditis sp. SL0708 (Rhabditida: Heterorhabditidae) isolated from soil in Alcalá, Valle del Cauca (Colombia) was characterised ecologically using Galleria mellonella larvae (L) (Pyralidae: Galleriinae) as hosts. The effect of temperature on the viability, infectivity and reproduction, and of moisture on infectivity and storage in liquid were evaluated in infective juveniles (IJs). Significant differences were found in the viability, infectivity and reproduction of the IJs at different temperatures. No nematodes were recovered at $5{ }^{\circ} \mathrm{C}$ and $10{ }^{\circ} \mathrm{C}$, and at $35^{\circ} \mathrm{C}$ no infectivity was observed. Average daily nematode recovery was best at $25^{\circ} \mathrm{C}$, and survival of the IJs was low in substrates presenting $13 \%$ moisture. The optimal storage temperature for Heterorhabditis sp. SL0708 was between $20^{\circ} \mathrm{C}$ and $30^{\circ} \mathrm{C}$, keeping its infectivity for up to 8 weeks.
\end{abstract}

Keywords: Rhabditida, infective juveniles, Heterorhabditidae, temperature, moisture, storage.

\section{Caracterização ecológica do nematoide entomopatogênico colombiano Heterorhabditis sp. SL0708}

\begin{abstract}
Resumo
O nematoide entomopatogênico colombiano Heterorhabditis sp. SL0708, isolado do solo de Alcalá, Valle del Cauca (Colombia), foi caracterizado ecologicamente utilizando-se como hospedeiro lagartas de Galleria mellonella (L) (Pyralidae:Galleriinae). O efeito da temperatura na viabilidade, na infecção e na reprodução, e da umidade na infecção e do armazenamento em líquido foi avaliado em juvenis infectantes (JIs). Diferenças significativas na viabilidade, na infecção e na reprodução dos JIs foram observadas nas diferentes temperaturas. Não foram recuperados nematoides a $5{ }^{\circ} \mathrm{C}$ e $10^{\circ} \mathrm{C}$, e não se observou infecção a $35^{\circ} \mathrm{C}$. A maior média diária de recuperação de nematoides foi a $25^{\circ} \mathrm{C}$. Por outro lado, a sobrevivência dos JIs foi baixa nos substratos com unidades de $13 \%$ e a melhor temperatura de armazenamento para SL0708 foi entre $20{ }^{\circ} \mathrm{C}$ e $30{ }^{\circ} \mathrm{C}$, mantendo a infecção até oito semanas.
\end{abstract}

Palavras-chave: Rhabditida, juvenis infectantes, Heterorhabditidae, temperatura, umidade, armazenamento.

\section{Introduction}

Entomopathogenic nematodes (NE) are organisms suitable for pest control (Sáenz, 2005), and compared to other methods of insect control their use has recently increased. Most species of Heterorhabditis and Steinernema have been isolated from soil samples using Galleria mellonella larvae (L), (Lepidoptera: Pyralidae), in general, little information is provided on their biology and ecology and they are not complemented in subsequent studies, this may hinder their use as biological control agents in integrated pest management systems despite being obligated pathogens of a wide range of hosts (Hazir et al., 2004, Morton and Garcia-del -Pino, 2009), having a mutualistic relationship with bacteria of the Photorhabdus and Xenorhabdus genera (Adams et al., 2006), high virulence and specific ecological characteristics (Lewis et al., 2006; Rohde et al., 2010; Strauch et al., 2000).

In the present study, we provide the ecology of the entomopathogenic nematode Heterorhabditis sp. SL0708, consistent with recommendations by Koppenhöfer and Kaya (1999). Heterorhabditis sp. SL0708 was isolated from bamboo-soil in the town of Alcalá - Valle del Cauca, Colombia. The life cycle of this nematode is known; (Sáenz and López, 2011), its virulence in G. mellonella, Plutella xyllostella L (Lepidoptera: Yponomeutidae), Delia platura 
Meigen (Diptera: Anthomyiidae), Collari scenica Stal (Hemiptera: Miridae) and Conatrachellus psidii Marshall (Coleoptera curcullionidae) (data in press) as well as its biology (Mejia and Sáenz, 2013). However, the effect of environmental conditions and of the storage method on the viability, reproductive capacity and the infectiousness of infective juveniles (IJs) are unknown, although this information is fundamental for the use of Heterorhabditis sp. SL0708 as a biological control agent.

\section{Material and Methods}

\subsection{General test conditions}

The tests were conducted at the Pontificia Universidad Javeriana's (PUJ) biological control laboratory at a temperature of $25^{\circ} \mathrm{C}$ and in darkness. Bioagro S.A., last instar larvae of $G$. mellonella weighing 250-300 mg were used in the reactivation and multiplication of the IJs, and in the development of bioassays. To carry out the different environmental performance tests, IJs were recovered between 5 and 7 days, and White traps were recovered and stored in sterile distilled water at $10{ }^{\circ} \mathrm{C}$.

\subsection{IJs tolerance to different temperatures}

To establish a temperature range in which Heterorhabditis sp. SL0708 remains viable, 100 IJs were inoculated into $1 / 2$ oz plastic containers filled with $8 \mathrm{~g}$ of sterile river sand at field capacity. 60 containers were incubated at 5, 10, 20, 25, 30 and $35^{\circ} \mathrm{C}$ for 2, 4, 6, 8, 10 and 12 hours. Once the time of exposure to the different temperatures elapsed, the containers were kept at $25{ }^{\circ} \mathrm{C}$ for $24 \mathrm{~h}$. To establish IJs viability, Baermann funnels were set-up for each sand sample. After a period of 4 hours a count of the IJs was conducted using a stereomicroscope.

\subsection{The effect of temperature on infectivity}

To determine the optimal temperature range in which Heterorhabditis sp. SL0708 can infect last instar larvae of $G$. mellonella, 20 individual larvae were exposed to $50 \mathrm{IJs}$ in $1 / 2 \mathrm{oz}$ plastic containers with $2 \mathrm{~g}$ of sterile river sand and incubated at $5,10,20,25,30,35^{\circ} \mathrm{C}$. Larvae mortality was assessed every 24 hours. Dead larvae were placed in Petri dishes on filter paper at $25{ }^{\circ} \mathrm{C}$ (Table 1). After 48 hours, the dead larvae were washed with sterile distilled water and dissected to determine the number of nematodes established in each dead larva.

\subsection{The effect of temperature on reproduction}

To establish the optimal temperature range for Heterorhabditis sp. SL0708 reproduction, 50 larvae were

Table 1. Range of temperature and infectivity incubation period for Heterorhabditis sp. SL0708.

\begin{tabular}{cc}
\hline $\begin{array}{c}\text { Range of temperature } \\
\text { used (in }{ }^{\circ} \mathbf{C} \text { ) }\end{array}$ & $\begin{array}{c}\text { Incubation period } \\
\text { (in days) }\end{array}$ \\
\hline $5-10$ & 3 \\
$15-20$ & 2 \\
$25-37$ & 1 \\
\hline
\end{tabular}

exposed to $50 \mathrm{IJs}$ in $1 / 2 \mathrm{Oz}$ plastic containers filled with $2 \mathrm{~g}$ of sterile river sand at field capacity and were kept until death was recorded. The dead larvae were placed in White traps and incubated at $5,10,20,25$ and $30{ }^{\circ} \mathrm{C}$ until the emergence of the IJs.

\subsection{IJs tolerance to different levels of soil water content}

To determine the range of soil water potential in which IJs of Heterorhabditis sp. SL0708 can seek and infect the host, 50 plastic, $1 / 2 \mathrm{oz}$ containers with $2 \mathrm{~g}$ of river sand were inoculated with 1000 IJs in $10 \mu \mathrm{l}$ of sterile distilled water. A G. mellonella larva was exposed in each container for a period of 48 hours. The potential soil moisture (\% w/w soil water content) assessed was $-5.5 \mathrm{kPa}(13 \%),-14 \mathrm{kPa}$ (33\%), $-43 \mathrm{kPa}$ (100\% field capacity), $-58 \mathrm{kPa}(133 \%)$ and $73 \mathrm{kPa}(166 \%)$. After the incubation period, the larvae were dissected so as to count the number of nematodes established in the host and the latter's mortality rate. Furthermore, the number of living IJs obtained from the Baermann funnels from each sand sample was also calculated.

\subsection{The effect of storage period}

To determine the optimal storage conditions for Heterorhabditis sp. SL0708, a suspension in sterile distilled water of $2000 \mathrm{IJs} / \mathrm{mL}$ for one day with recovered dead G. mellonella larvae, was placed in 72 tissue culture flasks of $50 \mathrm{ml}$ and exposed to temperatures of $5,10,15$ and $25^{\circ} \mathrm{C}$. Subsequently, three flasks per treatments were sampled randomly every $1,2,4,8$ and 16 weeks to evaluate the viability and infectivity of the IJs. Viability was established by counting the mobile IJs using a stereomicroscope and determining the survival percentage. In order to evaluate infectivity, 10 individual larvae were exposed to $25 \mathrm{IJs}$ for a period of three days in plastic containers of $1 / 20 z$ filled with $3 \mathrm{~g}$ of sterile river sand. After the incubation period, the dead larvae were washed, dissected and the number of nematodes in them was counted. 10 larvae placed with 25 newly retrieved IJs were used as a control.

\subsection{Data analysis}

Excluding the storage test, all the experiments were conducted twice. In all cases, the results of both tests were similar and were combined for analysis. The variance analysis and Tukey's HSD mean separation test $(\mathrm{P}<0.05)$ were performed using SPSS 18 (SPSS, 2009).

\section{Results}

Exposing the Heterorhabditis sp. SL0708 IJs to different temperatures, significant differences in their viability $(\mathrm{df}=5,54 ; \mathrm{F}=60.123, \mathrm{P}=0.0002$; Figure 1$)$ and infectivity $(\mathrm{df}=5,114 ; \mathrm{F}=123, \mathrm{P}=0.0002$; Figure 2$)$ were found. Upon completing the maximum exposure time, the percentage of survival and infectivity was between 0 and $3 \%$ at temperatures of 5 and $10^{\circ} \mathrm{C}$. At $35^{\circ} \mathrm{C}$, G. mellonella presented no evidence of infection. Similarly, reproduction is affected by temperature $(\mathrm{df}=4$, $45 ; \mathrm{F}=6.215, \mathrm{P}=0.0004)$. At 5 and $10{ }^{\circ} \mathrm{C}$ the life cycle was not completed. The recovery of IJs was similar in all 


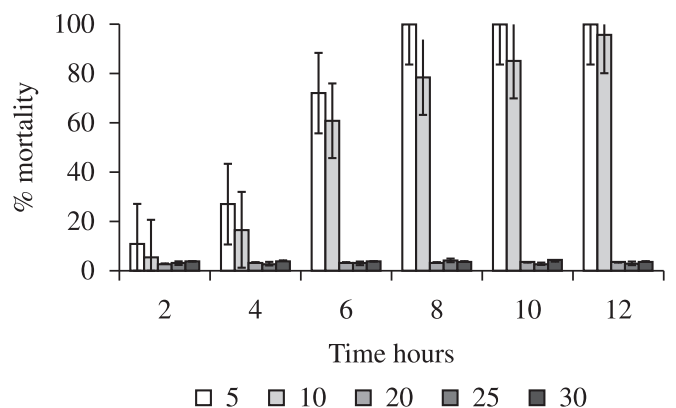

Figure 1. Heterorhabditis sp. SL0708 viability at five temperatures. The error bars were calculated using the standard deviation of each treatment.

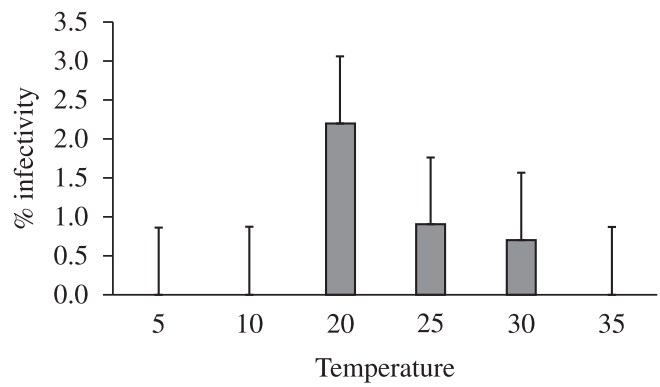

Figure 2. Heterorhabditis sp. SL0708 infectivity on Galleria mellonella exposed to six temperatures. The error bars were calculated using the standard deviation of each treatment.

the three treatments at temperatures of 20,25 and $30{ }^{\circ} \mathrm{C}$ (Figure 3). IJs tolerance tests at different moisture levels presented significant differences between treatments $(\mathrm{df}=4$, $45 ; \mathrm{F}=180.971, \mathrm{P}=0.0002$ ), a mortality of $73.45 \%$ was obtained in IJs exposed to $13 \%$ moisture after 48 hours (Figure 4). In $100 \%$ humidity, a mortality of $95 \%$ in G. mellonella larvae exposed to these IJs was recorded (Figure 4). Finally, in evaluating Heterorhabditis sp. SL0708 IJs temperature and storage time, significant differences $(\mathrm{df}=3,68 ; \mathrm{F}=132.140, \mathrm{P}=0.0001)$ were found in the nematodes' viability. The IJs survive up to eight weeks at temperatures between 20 and $30^{\circ} \mathrm{C}$ (Figure 5). Infectivity was reduced over time in all treatments; however at $25^{\circ} \mathrm{C}$ infectivity exceeded 50\% until the eighth week (Table 2).

\section{Discussion}

To study the ecology of entomopathogenic nematodes, tests must be conducted to evaluate the behaviour of IJs in different temperatures and humidity. It is recognised that temperature is an important factor in the life cycle of entomopathogenic nematodes (Griffin, 1993). Varying temperatures have effects on the viability of the IJs and their ability to reproduce, these effects are observed mainly in extreme temperatures $\left(0\right.$ and $\left.40{ }^{\circ} \mathrm{C}\right)$, which are lethal (Rohde et al., 2010; Susurluk, 2008; Morton and Garcia-del-Pino, 2009). As observed in Heterorhabditis sp. SL0708, low temperature reduces the IJs' mobility and persistence.

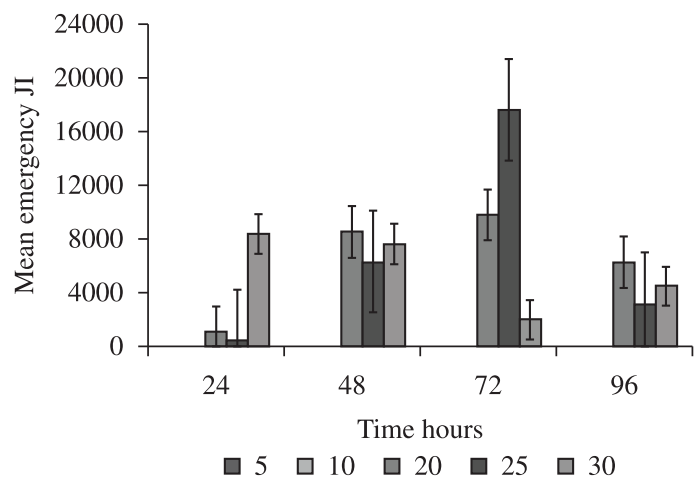

Figure 3. Heterorhabditis sp. SL0708 IJs emergence at five temperatures. The error bars were calculated using the standard deviation of each treatment.

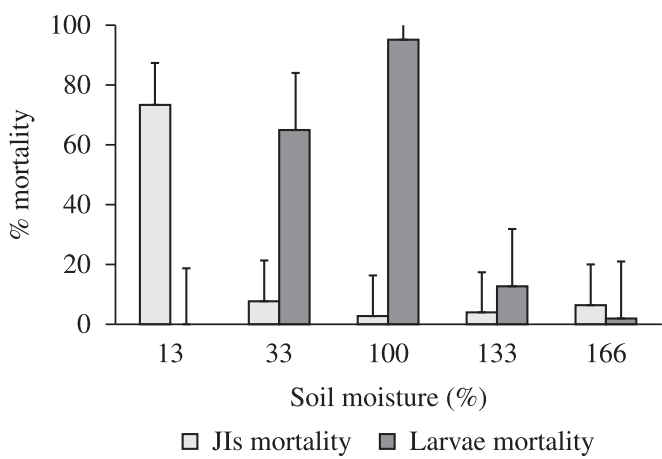

Figure 4. Heterorhabditis sp. SL0708 IJs mortality and Galleria mellonella infection at different moistures. The error bars were calculated using the standard deviation of each treatment.

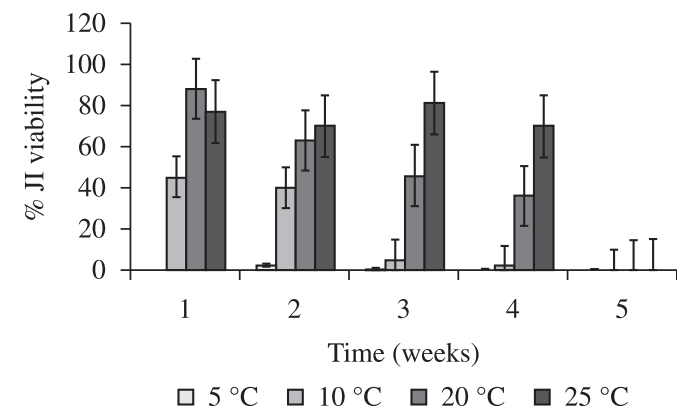

Figure 5. Heterorhabditis sp. SL0708 suspension viability under four storage temperatures. The error bars were calculated using the standard deviation of each treatment.

The results obtained with Heterorhabditis sp. SL0708 at temperatures between 20 and $35^{\circ} \mathrm{C}$, show the persistence of IJs in time, this is consistent with Koppenhöfer and Kaya (1999), who state that these temperatures are suitable for nematode pathogenicity, infectivity and reproduction. The survival of IJs in this temperature range indicates that it is optimal for this Colombian isolate and should not be generalised to other species, as the temperature ranges 
Table 2. Percentage of Heterorhabditis sp. SL0708 infection at different temperatures.

\begin{tabular}{ccccc}
\hline \multirow{2}{*}{ Temperature $\left({ }^{\circ} \mathbf{C}\right)$} & \multicolumn{5}{c}{ \% Infection } \\
\cline { 2 - 5 } & $\mathbf{1}$ & $\mathbf{2}$ & $\mathbf{4}$ & $\mathbf{8}^{*}$ \\
\hline 5 & 0 & 0 & 0 & 0 \\
10 & $80-100$ & $70-90$ & 0 & 0 \\
20 & $80-100$ & $70-100$ & $60-70$ & 50 \\
25 & $80-90$ & $80-100$ & $70-80$ & $40-60$
\end{tabular}

* Due to nematode death, no infectivity was assessed at 16 weeks.

affecting IJs vary depending on the geographic area where they are collected (Molyneux,1986). Specifically for Heterorhabditis sp. SL0708, exposure to temperatures between 20 and $30^{\circ} \mathrm{C}$ does not affect their viability over time, which is within the range established for other heterorhabditidae and some steinernematidae. An example of this is $H$. bacteriophora, individuals which can be recovered at temperatures up to $37^{\circ} \mathrm{C}$ while other species such as Steinernema carpocapsae and Steinernema feltiae can only be recovered at temperatures up to $35^{\circ} \mathrm{C}$ (Morton and Garcia-del-Pino, 2009). The infectivity of Heterorhabditis sp. SL0708 JIs is affected at temperatures below $20^{\circ} \mathrm{C}$ while inexistent at $5^{\circ}$ and $10^{\circ} \mathrm{C}$. The results are similar to those obtained by Chen et al. (2003), Morton and Garcia-del-Pino (2009) and Saunders and Webster (1999), who report that at temperatures below $15{ }^{\circ} \mathrm{C}$ infection is not good, while at temperatures between 15 and $35^{\circ} \mathrm{C}$ infectivity is optimal. In the case of Heterorhabditis sp. SL0708, greatest infectivity is presented at $20^{\circ} \mathrm{C}$, diverging from results found by Morton and Garcia-del-Pino (2009) for some species of heterorhabditidae, where $25^{\circ} \mathrm{C}$ was the optimum temperature or $30{ }^{\circ} \mathrm{C}$ for Heterorhabditis georgiana (Shapiro-Ilan et al., 2009). The inconsistency in results regarding temperature for different species of the Heterorhabditis genus, shows that a single temperature cannot be assigned to the genre and that the infectivity of nematode species may also depend on the size of the larva, the depth of the host in the substrate and search behaviour of the IJs (Boff et al., 2001; Susurluk, 2008).

While each temperature affects the percentage of infection of hosts by the IJs, it also generates a different impact on the life cycle inside the host. The main difference between treatments regarding the reproduction of Heterorhabditis sp. SL0708 was observed with the emergence of IJs from the dead G. mellonella, as described by Koppenhöfer and Kaya (1999). The results obtained with Heterorhabditis sp. SL0708 are similar to those reported by Morton and Garcia-del-Pino (2009) who state that the first emergence of the nematodes at $20^{\circ} \mathrm{C}$ occurs after 20 days, and at lower temperatures after 45 days following infection; however, although the emergence of Heterorhabditis sp. SL0708 came earlier at $20^{\circ} \mathrm{C}$, the number of nematodes recovered is greater at $25^{\circ} \mathrm{C}$, indicating that this is the optimum temperature and is favourable for the reproduction and recovery of IJs (Sáenz and López, 2011). This is consistent with results for $H$. bacteriophora and Steinernema rarum (Koppenhöfer and Kaya 1999; Morton and Garcia-delPino 2009).

Soil moisture is also an important factor for nematode mobility and survival (Hominick, 1990, Rohde et al., 2010). Heterorhabditis sp. SL0708 had poor survival in substrates with low humidity, this is in agreement with observations by Glazer (2002), Grewal et al. (2006), Mukuka et al. (2010) and Shapiro-Ilan et al. (2005), who point out Heterorhabditis's low potential to survive desiccation. According to studies by Koppenhöfer and Fuzy (2007), O'Leary et al. (2001) and Rohde et al. (2010) nematode viability is affected when suddenly exposed to dry soil, but if humidity is decreased progressively, the nematode can adapt and enter anhydrobiosis. Accordingly, the exposure of Heterorhabditis sp. SL0708 to low percentages of moisture may have caused the high mortality rate; therefore, future trials would be relevant to evaluate the feasibility and adaptability of the nematode in a gradual desiccation process.

Viability during storage in liquid was slightly affected after 8 weeks at $10{ }^{\circ} \mathrm{C}$, this is despite findings indicating viability, depending on the species, for periods of 3 to 4 months and temperatures of 8 and $15^{\circ} \mathrm{C}$ (Molina et al., 2006). For instance, Klingler (1990) reports for H. bacteriophora an optimal storage temperature of $6{ }^{\circ} \mathrm{C}$ for a period of 9 weeks with high viability and no effect on infectivity. Fitters and Griffin (2004) established for three strains of $H$. megidis a viability of over $80 \%$ after 6 weeks of storage at $20^{\circ} \mathrm{C}$. For $H$. indica and H. bacteriophora, Strauch et al. (2000) reported finding less than $20 \%$ of live IJs following 4 months of storage in liquid. Unlike reports for the Colombian Heterorhabditis sp. SL0708 nematode, which survived for periods of up to 8 weeks, no survival was established for any of these species at temperatures exceeding $20^{\circ} \mathrm{C}$. Although concentration for storage in liquid is typically $2000 \mathrm{JI} / \mathrm{mL}$, it is possible that the concentration of nematodes per $\mathrm{mL}$ affected the results, given that Molina et al. (2006) found that the best concentration to store Heterorhabditidae is $1000 \mathrm{JI} / \mathrm{mL}$ for a period of 15 days and one month at a temperature between 16 and $24^{\circ} \mathrm{C}$. Additional trials utilising other methods of storage are needed to attain longer periods of viability for Heterorhabditis sp. SL0708.

Acknowledgements - To Colciencias and Pontificia Universidad Javeriana for funding this research, which is part of the Project Evaluating the goods and services of biodiversity for the sustainable development of Colombian rural landscapes: Complejo Ecorregional Andes del Norte, from the Centro de Investigaciones y Estudios en Biodiversidad y Recursos Genéticos (CIEBREG). We also thank the owners and personnel in charge of the Ramada, Floresta, and Topacio productive systems for permitting access to the study zones.

\section{References}

ADAMS, B., FODOR, A., KOPPENHÖFER, H., STACKEBRANDT, E., STOCK, SP. and KLEIN, M., 2006. Biodiversity and systematic of nematode-bacterium entomopathogens. Biological Control, vol. 37, p. 32-49. http://dx.doi.org/10.1016/j.biocontrol.2005.11.008 
BOFF, MIC., WIEGERS, GL. and SMITS, PH., 2001. Host influences on the pathogenicity of Heterorhabditis megidis. BioControl, vol. 46, p. 91-103. http://dx.doi.org/10.1023/A:1009937407899

CHEN, S., LI, J., HAN, X. and MOENS, M., 2003. Effect of temperature on the pathogenicity of entomopathogenic nematodes (Steinernema and Heterorhabditis spp.) to Delia radicum. BioControl, vol. 48, p. 713-724. http://dx.doi.org/10.1023/A:1026341325264

FITTERS, PFL. and GRIFFIN, CT., 2004. Spontaneous and induced activity of Heterorhabditis megidis infective juveniles during storage. Nematology, vol. 6, p. 911-917. http://dx.doi. org/10.1163/1568541044038597

GLAZER, I., 2002. Survival Biology. In GAUGLER, R. (Ed.). Entomopathogenic nematology. New York: CABI Publishing Series. p. 169-187. http://dx.doi.org/10.1079/9780851995670.0169

GREWAL, PS., BORNSTEIN-FORST, S., BURNELL, AM., GLAZER, I. and JAGDALE, GB., 2006. Physiological, genetic and molecular mechanisms of chemoreception, thermobiosis and anhydrobiosis in entomopathogenic nematodes. Biological Control, vol. 38:54-65. http://dx.doi.org/10.1016/j.biocontrol.2005.09.004

GRIFFIN, CT. 1993. Temperature responses of entomopathogenic nematodes: implication for the success of biological control progammes. In BEDDING, R., AKHURST, R. and KAYA, H. (Eds) Nematodes and the biological control of insect pests. EastMelbourne Victoria 3002. p. 115-126.

HAZIR, S., KAYA, HK., STOCK, P. and KESKIN, N., 2004. Entomopathogenic Nematodes (Steinernematidae and Heterorhabditidae) for biological control of soil pests. Turkish Journal of Biology, vol. 26, p. 181-202.

HOMINICK, WM., 1990. Entomopathogenic rhabditid nematodes and pest control. Parasitology, vol. 6, p. 148-152.

KLINGLER, J., Effect of cold storage on survival and parasitic activity of Heterorhabditis sp. Entomophaga, vol. 35, no. 3, p. 493-496, 1990. http://dx.doi.org/10.1007/BF02375275

KOPPENHÖFER, AM. and FUZY, E., 2007. Soil moisture effects on infectivity and persistence of the entomopathogenic nematodes Steinernema scarabaei, S. glaseri, Heterorhabditis zealandica, and H. bacteriophora. Applied Soil Ecology, vol. 35, p. 128-139. http://dx.doi.org/10.1016/j.apsoil.2006.05.007

KOPPENHÖFER, AM. and KAYA, H., 1999. Ecological characterization of Steinernema rarum. Journal of Invertebrate Pathology, vol. 73, p. 120-128. PMid:9878298. http://dx.doi. org/10.1006/jipa.1998.4822

LEWIS, EE., CAMBELL, J., GRIFFIN, C., KAYA, H. and PETERS, A., 2006. Behavioral ecology of entomopathogenic nematodes. Biological Control, vol. 38, p. 66-79. http://dx.doi. org/10.1016/j.biocontrol.2005.11.007

MEJÍA-TORRES, MC. and SÁENZ, A., 2013. Biological characterization of the colombian isolate Heterorhabditis sp. SL0708 (Rhabditida: Heterorhabditidae). Acta ScientiarumBiological Sciences. In press.

MOLINA, JP., MOINO, JRA., SOUSA, R., ANDALÓ, V. and APARECIDA, L., 2006. Efecto de temperatura, concentración y tiempo de almacenamiento en la supervivencia de nemátodos entomopatógenos. Revista Colombiana de Entomología, vol. 32, p. 24-30.

MOLYNEUX, AS., 1986. Heterorhabditis spp. and Steinernema spp.: temperature and aspects of behavior and infectivity.
Experimental Parasitology, vol. 62, p. 169-180. http://dx.doi. org/10.1016/0014-4894(86)90021-4

MORTON, A. and GARCIA-DEL-PINO, F., 2009. Ecological characterization of entomopathogenic nematodos isolated in stone fruit orchard soils of Mediterranean areas. Journal of Invertebrate Pathology, vol. 102, p. 203-213. PMid:19679134. http://dx.doi. org/10.1016/j.jip.2009.08.002

MUKUKA, J., STRAUCH, O., HOPPE, C. and EHLERS, R-U., 2010. Fitness of heat and dessiccation tolerant hybrid strains of Heterorhabditis bacteriophora (Rhabditidomorpha: Heterorhabditidae). Journal of Pest Science, vol. 83, p. 281-287. http://dx.doi.org/10.1007/s10340-010-0296-3

O'LEARY, SA., POWER, AP., STACK, CM. and BURNELL, AM., 2001. Behavioural and physiological responses of infective juveniles of the entomophatogenic nematode Heterorhabditis to dessication. BioControl, vol. 46, p. 345-362. http://dx.doi. org/10.1023/A:1011470021857

ROHDE, C., MOINO JUNIOR, A., SILVA, MA., CARVALHO, FD. and FERREIRA, CS., 2010. Influence of soil temperature and moisture on the infectivity of entomopathogenic nematodes (Rhabditida: Heterorhabditidae, Steinernematidae) against larvae of Ceratitis capitata (Wiedemann) (Diptera: Tephritidae). Neotropical Entomology, vol. 39, p. 608-611. PMid:20877999. http://dx.doi. org/10.1590/S1519-566X2010000400022

SÁENZ, A., 2005. Importancia de los nemátodos entomopatógenos para el control biológico de plagas en palma de aceite. Palmas, vol. 26, p. 41-57.

SÁENZ, A. and LÓPEZ, JC., 2011. Ciclo de vida y Patogenicidad de un aislamiento nativo de Heterorhabditis sp., (Rhabditida: Heterorhabditidae). Revista Colombiana de Entomología, vol. 37, no. 1, p. 43-47.

SAUNDERS, JE. and WEBSTER, J.M., 1999. Temperature Effects on Heterorhabditis megidis and Steinernema carpocapsae Infectivity to Galleria mellonella. Journal of Nematology, vol. 31, p. 299-304. PMid:19270900 PMCid:2620370.

SHAPIRO-ILAN, DI., STUART, RJ. and McCOY, CW., 2005. Characterization of biological control traits in the entomopathogenic nematode Heterorhabditis mexicana (MX4 strain). Biological Control, vol. 32, p. 95-103.

SHAPIRO-ILAN, DI., MBATA, GN., NGUYEN, KB., PEAT, SM., BLACKBURN, D. and ADAMS, B. 2009. Characterization of biocontrol traits in the entomopathogenic nematode Heterorhabditis georgiana (Kesha strain) and phylogenetic analysis of the nematode's symbiotic bacteria. Biological Control, vol. 51, p. 377-387. http:// dx.doi.org/10.1016/j.biocontrol.2009.07.009

Statistical Package for the Social Sciences - SPSS, 2009. Base 18.0. Usur's Guide. Chicago: SPSS Inc., United States of America.

STRAUCH, O., NIEMANN, I., NEUMANN, A., SCHMIDT, AJ., PETERS, A. and EHLERS, R-U. 2000. Storage and formulation of the entomopathogenic nematodes Heterorhabditis indica and H. bacteriophora. BioControl, vol. 45, p. 483-500. http://dx.doi. org/10.1023/A:1026528727365

SUSURLUK, J., 2008. Potential of the entomopathogenic nematodes Steinernema feltiae, S. weiseri and Heterorhabditis bacteriophora for the biological control of the sugar beet weevil Bothynoderes punctiventris (Coleoptera: Curculionidae). Journal of Pest Science, vol. 81, p. 221-225. http://dx.doi.org/10.1007/ s10340-008-0209-x 